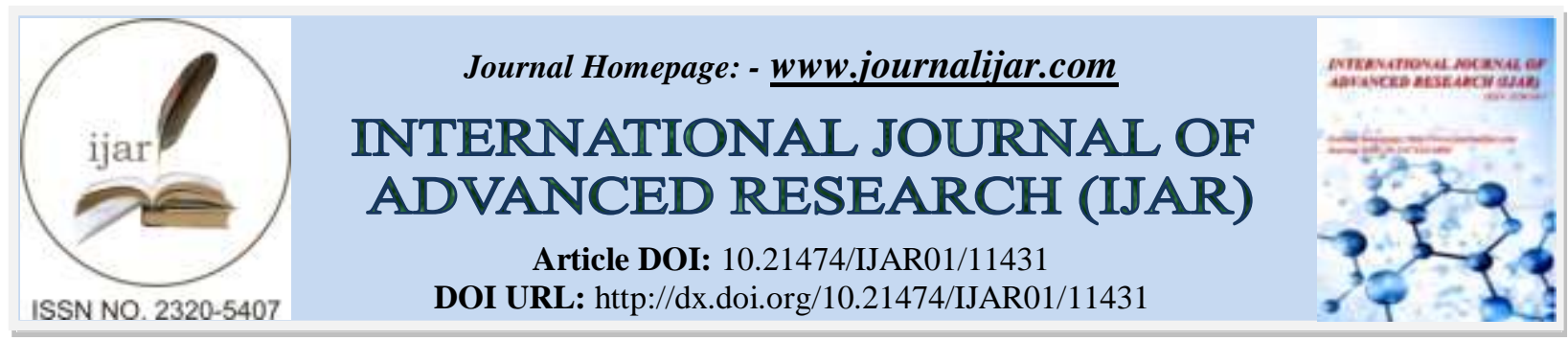

RESEARCH ARTICLE

\title{
ASSESSMENT OF ORAL TOXICITY, SKIN AND EYE IRRITATION OF CYMBOPOGON NARDUS (L.) RENDLE (POACEAE) ESSENTIAL OIL FROM BURKINA FASO
}

\section{Geoffroy Gueswindé Ouédraogo ${ }^{1}$, Ignace Sawadogo ${ }^{2}$, Jean Noël Dado Koussé ${ }^{3}$, Sylvain Ilboudo ${ }^{1,4}$, Boubacar} Tounkara $^{3}$, Moussa Ouédraogo ${ }^{3}$, Roger Ch. H. Nébié $^{2}$ and Sylvin Ouédraogo ${ }^{1}$

1. Département de Médecine et Pharmacopée Traditionnelles et Pharmacie, Institut de Recherche enSciences de la Santé, Centre National de la Recherche Scientifique et Technologique (MEPHATRA-PH/IRSS/CNRST), 03 BP 7192 Ouagadougou 03, Burkina Faso.

2. Département Substances Naturelles, Institut de Recherche en Sciences Appliquées et Technologies (DSN/IRSAT/CNRST), 03 BP 7047 Ouagadougou 03, Burkina Faso.

3. Unité de Formation et de Recherche en Sciences de la Santé (UFR/SDS), Université Joseph KI-ZERBO,03 BP 7021 Ouagadougou 03, Burkina Faso.

4. Unité Mixte de Recherche Internationale - Environnement, Santé, Sociétés (UMI 3189, ESS) CNRST/CNRS/UCAD/UGB/USTTB, Burkina Faso.

\section{Manuscript Info}

Manuscript History

Received: 28 May 2020

Final Accepted: 30 June 2020

Published: July 2020

\section{Key words:-}

Cymbopogon Nardus, Wistar Rat, Essential Oil, Acute And Subacute Toxicity, Rabbit, Irritation, Biochemical Parameters
Abstract

Cymbopogon nardus (L.) Rendle (Poaceae) (C. nardus) still known as Ceylon citronella is an aromatic plant imported from India, Sri Lanka and introduced to the rest of the world including Africa. In Burkina Faso, the essential oil (EO) of this plant is used to formulate biopesticides. The objectives of this study consisted of evaluating the toxicological profile of the EO of $C$. nardus for its safe use. Acute and sub-acute oral toxicity was assessed on Wistar rats and skin, and eye irritant power was determined on rabbits according to the Organization for Economic Cooperation and Development (OECD) guidelines. In Acute oral toxicity test, a single administration of EO at a dose of 2000 $\mathrm{mg} / \mathrm{kg}$.b.w. to rats did not result in mortality or sign of toxicity. The LD50 of this EO is estimated to $5000 \mathrm{mg} / \mathrm{kg}$ b.w. The 28 days subacute toxicity study with doses of 100,500 and $1000 \mathrm{mg} / \mathrm{kg}$.b.w of EO did not show mortality in both sexes. Furthermore, there was no significant difference observed in body weight gain, relative organ weights, food and water consumption in test groups compared to control ones. However, there was a significant increase in AST, creatinine levels at a dose of $1000 \mathrm{mg} / \mathrm{kg}$. b.w. and total protein at tested doses in both sexes. The skin and eye irritation studies on rabbit show that the EO had a very weak irritant power on the skin and the eye. These results suggested that $C$. nardus EO can constitute an alternative to synthetic pesticides and used in biopesticides formulation.

Copy Right, IJAR, 2020,. All rights reserved.

Corresponding Author :- Geoffroy Gueswindé Ouédraogo

Address :- Département Médecine et Pharmacopée Traditionnelles et Pharmacie, Institut de Recherche en Sciences de la Santé, Centre National de la Recherche Scientifique et Technologique (MEPHATRAPH/IRSS/CNRST), 03 BP 7192 Ouagadougou 03, Burkina Faso. 


\section{Introduction:-}

Synthetic pesticides are a heterogeneous group of chemicals used against plants and pests (insects, rodents, mould, weeds, etc.) (Cherin et al., 2012). They are used in rural areas to fight against crop pests, but also to preserve foodstuffs such as millet, corn, rice, cowpeas, etc.(Waongo et al., 2013; Zongo et al., 2015). However, nowadays, these chemical pesticides are a source of problems because they are responsible for acute and chronic intoxication with harmful effects on the health of populations and their environment (Blanc-Lapierre et al., 2012; Cherin et al., 2012; Ilboudo et al., 2014; Multigner, 2005). According to the World Health Organization (WHO) in 2004, there are between one to five million poisonings of chemical pesticides each year worldwide, which are responsible for several thousand deaths per year (OMS, 2004). Face to these public health and environmental problems linked to synthetic pesticides; research is underway to formulate pesticides that are more effective against pests and less harmful to humans and the environment. Biopesticides are presented as an alternative to synthetic pesticides. Biopesticides are living organisms or products from these organisms with the particularity of suppressing or limiting the proliferation of pests. These pesticides of natural origin are distinguished in three main categories according to their microbial, plant or animal origin (Deravel et al., 2014).

Cymbopogon nardus (L.) Rendle(C. nardus) or Ceylon citronella is a plant native to southern India and Sri Lanka and introduced to other countries including Burkina Faso. It is a herbaceous plant of the Poaceae family which is commonly cultivated. It is perennial, green, forming dense tufts of 1 to $1.8 \mathrm{~m}$ in high (Prelude medicinal plants database, 2019). In Burkina Faso, the essential oil (EO) of this plant is used to formulate biopesticides. A study carried out in Ivory Coast, showed that the EO of C. nardus contains molecules such as citronellol, limonene, with the citronellal as the majority chemical molecule (42.20\%) (Kanko et al., 2017). Studies carried out showed the insecticidal properties of $C$. nardus EO. In India, a study carried out have shown the effectiveness of this EO on some fungi which contaminate cereals and legumes (Kroet al., 2017). In Morocco, another study showed the antimicrobial efficacy of $C$. nardus EO on bacteria responsible for nosocomial infections (Kamari et al., 2018). There are several studies showing the pesticidal properties of the EO of $C$. nardus, but few authors have been interested in studying its toxicological profile.

The aim of this study was, therefore, to study the toxicological profile of $C$. nardus EO. It was more specifically a question of determining its acute and subacute oral toxicityand its skin and eye irritancy power in order to provide additional data on the safety of users of this plant EO.

\section{Material And Methods:-}

\section{Plant material:}

Fresh leaves of $C$. nardus were collectedfrom the botanical garden of the "Institut de Recherche en Sciences Appliquées et Technologies"(IRSAT), Bama, Burkina Faso (Latitude Nord $1122^{\prime} 00^{\prime \prime}$,_Longitude Ouest 4 25' 00"). After collection, the plant sample was identified and authenticated at "Herbier National du Burkina (HNBU)"of the "Centre National de Recherche Scientifique et Technologique (CNRST)", Ouagadougou (Burkina Faso). The fresh leaves were washed with tap water and keep according to good conservation practices and used later for the extraction of EO.

\section{Essential oil:}

A portion of fresh leaves ( $40 \mathrm{~kg}$ ) was submitted to hydrodistillation using an alembic/Clevenger-type apparatus for 3 h. After that, anhydrous sodium sulfate was used to remove water from the extract. The essential oil obtained was stored in an airtight container in a refrigerator at $4^{\circ} \mathrm{C}$ until toxicological tests (Bassolé et al., 2018).

\section{Animals:}

Healthy female and male Wistar rats weighing respectively between $110-140 \mathrm{~g}$ and 127-140 g were used for acute and sub-acute toxicity studies. They were provided from the pet shop of the "Institut de Recherche en Science de la Santé"(IRSS), Ouagadougou, Burkina Faso. The were housed in the animal cage with free access to water and standard laboratory pellet enriched with protein $(29 \%)$. All animals were kept in laboratory conditions (temperature room of $22^{\circ} \mathrm{C}( \pm 3)$ with a humidity rate of $60 \%( \pm 5)$ and $12 \mathrm{~h} \mathrm{light/dark} \mathrm{cycle)}$. 
Healthy female and male rabbits weighing between 1.67-2.09 kg were used for eyes and skin irritation tests. They were procured from breeders in the city of Ouagadougou and acclimatized during twoweeks in a ventilated room with free access to water and standard granula before use.

The experimental protocol was carried out following to the international standard protocols [Guidelines set by the European Union on the Protection of Animals (CEC Council 86/609)] and adopted by IRSS, Burkina Faso (Ilboudo et al., 2019; Konaté et al., 2016).

Acute orale toxicity test:

The acute oral toxicity test of $C$. nardus EO wasperformed on female rats according to the Organization for Economic Cooperation and Development (OECD) test guideline 423 (OCDE, 2001). After a fasting period (4 h of starvation only), $C$. nardus, was administered orally by gavage in a single dose to the rats according to the sequential procedure. In the conducting of the test, the starting dose of $2000 \mathrm{mg} / \mathrm{kg} \mathrm{b}$.w. of EO was administered to treated group. A control group received a single dose of distilled water orally. All animals were observed during the first 2 hours post-treatment before the restoration of food. They were then observed at least once a day for two weeks. The mortality and signs of toxicity such as changes in skin and fur, eyes, mucus membranes, salivation, convulsion, diarrhoea, lethargy, sleep and coma were notified during this observation period.

\section{Sub-acute oral toxicity test:}

The sub-acute oral toxicity studyof $C$. nardus EO was performed in accordance with OECD guideline 407 (OCDE, 2008). A total of 40 Wistarrats of both sexes were randomly selected for the sub-acute toxicity studies. The rats were divided into 4 groups of 10 animals each ( 5 per sex). Males and females rats were kept separately in cages. The control group (group 1), received distilled water. The others groups (groups 2 to 4) received a daily dose of 100, 500 and $1000 \mathrm{mg} / \mathrm{kg}$ b.w. of C. nardus EO at the same hour for 28 consecutive days respectively. Doses were prepared by dispersion of $C$. nardus $\mathrm{EO}$ in distilled water. All animals were closely observed the 4 first hours post-treatment to notified any signs of toxicity and at least once a day for mortality and morbidity. Water intake was monitored daily, while food and body weight was recorded once a week throughout the 28 days study period (Ilboudo et al., 2019; OCDE, 2008).

\section{Blood analysis:}

All animals fasted on the evening of the 28 days. On day 29th, the animals were an anesthetized with ketamine (150 $\mathrm{mg} / \mathrm{kg}$ ), and blood samples were collected from each animal via cardiac puncture into dry vacutainers. Blood samples were then centrifuged at $3000 \mathrm{rpm}$ for 10min using a table centrifuge (ROTOFIX 32A, Mettich Zenfrifugen, Germany) and the serum obtained wasused for serum biochemical analysis. Aspartate aminotransferase (AST), alanine aminotransferase (ALT), creatinine (CREAT), glucose, total cholesterol (TC) and total protein (TP) levels were determine dusing a semi-automatic biochemistry analyzer (MINDRAY BA-88A, China) (Ilboudo et al., 2019).

\section{Effects on vital organs:}

After blood collection, vital internal organs such as heart, liver, lungs, kidneys and spleen were removed, observed macroscopically for any lesions and weighed on a sensitive balance. The Relative Organ Weight (ROW) ratio of each organ was calculated according to the following formula:

$$
\text { ROW }(\%)=\frac{\text { Absolute organ weight }(\mathrm{g})}{\text { Body weight of rats on sacrifice day }(\mathrm{g})} \times 100
$$

\section{Skin irritation test of $C$. nardus EO:}

Skin irritation test was inspired by those of Draize (Draize et al., 1944) and adapted by the OECD guideline 404 for product testing using acute skin irritation/corrosion method (Draize et al., 1944; OCDE, 2015). The test was conducted using three adult male rabbits. Animals were shaved on the flanks $24 \mathrm{~h}$ before the application of the EO. A single dose of $C$. nardus EO $(0.5 \mathrm{~mL})$ isapplied for $4 \mathrm{~h}$ to a small area $\left(\approx 6 \mathrm{~cm}^{2}\right)$ of one flank, and the untreated skin area of animal had used as the control. At the end ofthe exposure period, patches were removed. Observations and rating of erythema and oedema were made after 1, 24, 48 and $72 \mathrm{~h}$ after the removal of the patch. The observations were continued up to 14 days for a possible change in behaviour, general condition, posture and reflexes (Ilboudo et al., 2019; OCDE, 2015). The reactions, defined as erythema and oedema, were evaluated according to the scoring system forskin reactions (OCDE, 2015). The Dermal Irritation Score (DIS) was calculated using the following formula: 


$$
\text { DIS }=\frac{\text { Value }(\text { erythema }+ \text { edema })}{\text { Number of animal } \times \text { Number of observations }}
$$

The EO's DIS wasclassifiedaccording to the scaleproposed by Draize, adapted by Dutokand adopted by OECD for determining thedegree of acute skin irritation/corrosion (Draize et al.,1944; OCDE, 2015; Dutok et al., 2015).

\section{Eye irritation test of $C$. nardus EO:}

The study was performed according to an adaptation of the OECD guidelines 405 for determining the degree of acute eye irritation/corrosion (OCDE, 2017). Three rabbits per group were constituted for experimental assays. Prior to test, they were subjected to a rigorous observation of the ocular structures such as the cornea, iris, and conjunctiva. After that, $0.1 \mathrm{~mL}$ of the EO was instilled in a single dose to the bottom of the right conjunctival sac of one eye of each animal and, keeping eyelids together over the next $30 \mathrm{~s}$. The other left eye (untreated one) served as control. Both eyes of each animal were observed, and the degree of eye irritation/corrosion is evaluated by scoring lesions of conjunctiva, cornea, and iris, at intervals of 1, 24, 48, and $72 \mathrm{~h}$. Ultraviolet light was used for observation (OCDE, 2017). The individual irritation score was determined usingthe scale of weighted scores for grading the severity of ocular lesions from Draize (Draize et al., 1944). The observations were allowed to continue up to 21 days to evaluate the reversibility or irreversibility of the effects. The Maximum Mean Total Score (MMTS) was determined using the following formula:

$$
\text { MMTS }=\frac{\text { Sum of total maximum score (rabbit } 1+\text { rabbit } 2+\text { rabbit } 3)}{3}
$$

The MMTS obtained were used for classification of eye irritability in the system of Kay and Calandra (Kay JH., Calandra JC., 1962).

\section{Data analysis:}

Results were expressed as mean \pm standard deviation SD $(n=5)$. The statistical significance of the difference between treatedand control groups was analyzed by One-way analysis of ANOVA, using GraphPad Prism 5 (GraphPad Software, SanDiego, CA, USA). Differences were considered statistically significant at $\mathrm{p}<5 \%$.

\section{Results:-}

\section{Acute oral toxicity study:}

Acute oral toxicity study was indicated that the $C$. nardus EO at a single dose of $2000 \mathrm{mg} / \mathrm{kg}$ b.w did not cause any remarkable behavioural changes or mortality of rats in the two steps. According to the acute toxicity class method of OECD 423 guideline, the $C$. nardus EO has an $\mathrm{LD}_{50}$ value estimated to $5000 \mathrm{mg} / \mathrm{kg}$ b.w. and is classified to the $5^{\text {th }}$ toxicity class (OCDE, 2001).

\section{Sub-acute oral toxicity study:}

During the subacute oral toxicity study period (28 days), no mortality was recorded. In addition, daily administration of $C$. nardus EO resulted in no behavioural changes in the treated rats compared to the control one.

\section{Effect on water and food consumption:}

Daily mean water and food consumption are presented in Tables 1 and 2, respectively. The averages of water and food consumption of treated groups werefound to besimilar to the control groups. However, a non-significant increase in water consumption during the 28 days study was observed to at 500 and $1000 \mathrm{mg} / \mathrm{kg} \mathrm{b.w.}$

\section{Bodyweight gain:}

Figure 1 shows the weekly mean weight changes of females and males rats, whichreceived 100,500 and 1000 $\mathrm{mg} / \mathrm{kg}$ b.w. EO of C. nardus for 28 days. These results show an increase in body weight of all animals (control and treated groups) during the 28 days of study. However, this increase was not significant to be attributed to the product.

\section{Effect of $C$. nardus EO on vital organs:}

Macroscopic examination in the fresh state of vital organs such as heart, lungs, liver, kidneys and spleen of control and treated rats with $C$. nardus EO showed that there was no change in colour and aspect of different organs extract 
does not affect vital organs as there was. Also, no significant change was noticed in relative organ weights (ROW) of control and treated animals with EO at doses of 100, 500 and $1000 \mathrm{mg} / \mathrm{kg} \mathrm{b.w.} \mathrm{(p>0.05)} \mathrm{(table} \mathrm{3).}$

\section{Effect of $C$. nardus EO on biochemical parameters:}

The results of serum biochemical analysis of treated and control groups are presented in table 4 . These results show that the daily oral administration of $C$. nardus EO at doses of 100, 500 and $1000 \mathrm{mg} / \mathrm{kg}$ b.w. on rats for 28 consecutive days did not cause significant changes in blood serum biochemical parameters such as ALT and glycemia levels in treated compared to control groups ( $p>0.05)$. However, a significant increase in AST level of male rats was observed in treated groups at doses of $1000 \mathrm{mg} / \mathrm{kg}$ b.w.when compared to control $(\mathrm{p}<0.05)$. Also, a significant decrease in total protein and creatinine levels in male rats and cholesterol level in female rat treated with $\mathrm{EO}$ at doses of 100, 500 and $1000 \mathrm{mg} / \mathrm{kg}$, were observed in treated groups compared to control ones $(\mathrm{p}<0.05)$.

\section{Acute skin irritation test of $\boldsymbol{C}$. nardus EO:}

In the acute skin irritation study, the results obtained indicate that $C$ nardus EO didn't cause any signs of erythema or oedema during the $72 \mathrm{~h}$ of observation after patch removal. The Dermal IrritationScore (DIS) for $C$. nardus EO found was "0.00" (Table 5). This product is classified as not irritant for skin according tothe scale proposed by Draize (Draize et al., 1944).

\section{Acute ocular irritation test of $C$. nardus EO:}

The results of eye irritation scores of $C$. nardus EO are presented in Table 6 . These results indicated that the Maximum Mean Total Score (MMTS) was 5.33 for the group of rabbits treated with the EO. According to classification in the system of Kay and Calandra (Kay JH., Calandra JC., 1962), C. nardus EO is classified as a substance with minimal irritation on the rabbit's eye.

Table1:- Mean daily water consumption (mL/day/rat) during 28 days treatment with C. nardus EO.

\begin{tabular}{|c|c|c|c|c|c|}
\hline \multirow{2}{*}{ Week } & Sex & \multicolumn{5}{|c|}{ Doses } \\
\cline { 3 - 6 } & & Control & $100 \mathrm{mg} / \mathrm{kg}$ & $500 \mathrm{mg} / \mathrm{kg}$ & $1000 \mathrm{mg} / \mathrm{kg}$ \\
\hline \multirow{2}{*}{ Week 1 } & $\mathrm{F}$ & $33.57 \pm 3.41$ & $29.00 \pm 2.65$ & $37.86 \pm 4.84$ & $34.29 \pm 4.27$ \\
\cline { 2 - 6 } & $\mathrm{M}$ & $37.86 \pm 3.34$ & $37.71 \pm 1.38$ & $38.71 \pm 3.45$ & $41.57 \pm 5.88$ \\
\hline \multirow{2}{*}{ Week 2 } & $\mathrm{F}$ & $38.71 \pm 6.05$ & $36.00 \pm 2.94$ & $41.43 \pm 4.61$ & $40.43 \pm 2.29$ \\
\cline { 2 - 6 } & $\mathrm{M}$ & $42.86 \pm 3.72$ & $42.00 \pm 3.61$ & $41.57 \pm 3.55$ & $46.14 \pm 7.43$ \\
\hline \multirow{2}{*}{ Week 3 } & $\mathrm{F}$ & $39.57 \pm 2.44$ & $36.43 \pm 3.21$ & $43.29 \pm 4.27$ & $43.86 \pm 3.63$ \\
\cline { 2 - 7 } & $\mathrm{M}$ & $46.71 \pm 5.47$ & $46.29 \pm 2.36$ & $48.14 \pm 5.82$ & $51.57 \pm 7.02$ \\
\hline \multirow{2}{*}{ Week 4 } & $\mathrm{F}$ & $40.57 \pm 6.24$ & $38.71 \pm 3.82$ & $47.29 \pm 5.02$ & $41.00 \pm 5.97$ \\
\cline { 2 - 7 } & $\mathrm{M}$ & $49.00 \pm 5.77$ & $50.71 \pm 3.90$ & $48.71 \pm 4.35$ & $54.86 \pm 7.67$ \\
\hline
\end{tabular}

Mean and standard deviation are presented $(n=10 ; 5 /$ sex $) M=$ Male $; \mathrm{F}=$ Female

Table 2:- Mean weekly food consumption (g/day/rat) during 28 days treatment with $C$. nardus EO.

\begin{tabular}{|c|c|c|c|c|c|}
\hline \multirow{2}{*}{ Week } & \multirow{2}{*}{ Sex } & \multicolumn{5}{|c|}{ Doses } \\
\cline { 2 - 6 } & & Control & $100 \mathrm{mg} / \mathrm{kg}$ & $500 \mathrm{mg} / \mathrm{kg}$ & $1000 \mathrm{mg} / \mathrm{kg}$ \\
\hline \multirow{2}{*}{ Week 1 } & $\mathrm{F}$ & 25.90 & 22.09 & 30.14 & 28.43 \\
& $\mathrm{M}$ & 26.06 & 33.55 & 29.54 & 34.49 \\
\hline \multirow{2}{*}{ Week 2 } & $\mathrm{F}$ & 25.61 & 20.00 & 25.48 & 17.33 \\
& $\mathrm{M}$ & 28.54 & 30.20 & 27.53 & 31.43 \\
\hline \multirow{2}{*}{ week 3 } & $\mathrm{F}$ & 28.06 & 21.51 & 26.23 & 25.51 \\
\cline { 2 - 6 } & $\mathrm{M}$ & 31.43 & 27.37 & 27.00 & 31.43 \\
\hline Week 4 & $\mathrm{F}$ & 26.86 & 18.66 & 20.17 & 21.06 \\
& $\mathrm{M}$ & 28.57 & 25.94 & 27.14 & 28.57 \\
\hline
\end{tabular}

Mean are presented $(\mathrm{n}=10 ; 5 / \mathrm{sex}) \mathrm{M}=$ Male; $\mathrm{F}=$ Female

Table 3:- Mean relative organ weights (\%) of rats after 28 days oftreatment with C. nardus EO.

\begin{tabular}{|c|c|c|c|c|c|}
\hline \multirow{2}{*}{ Organs } & \multirow{2}{*}{ Sex } & \multicolumn{4}{|c|}{ Doses } \\
\cline { 3 - 6 } & & Control & $100 \mathrm{mg} / \mathrm{kg}$ & $500 \mathrm{mg} / \mathrm{kg}$ & $1000 \mathrm{mg} / \mathrm{kg}$ \\
\hline Heart & $\mathrm{F}$ & $0.37 \pm 0.02$ & $0.42 \pm 0.05$ & $0.42 \pm 0.02$ & $0.39 \pm 0.04$ \\
\hline
\end{tabular}




\begin{tabular}{|c|c|c|c|c|c|}
\hline & $\mathrm{M}$ & $0.37 \pm 0.03$ & $0.37 \pm 0.04$ & $0.38 \pm 0.02$ & $0.39 \pm 0.02$ \\
\hline \multirow{3}{*}{ Lungs } & $\mathrm{F}$ & $0.62 \pm 0.05$ & $0.58 \pm 0.05$ & $0.80 \pm 0.39$ & $0.65 \pm 0.03$ \\
\cline { 2 - 5 } & $\mathrm{M}$ & $0.52 \pm 0.07$ & $0.58 \pm 0.12$ & $0.60 \pm 0.07$ & $0.60 \pm 0.07$ \\
\hline \multirow{2}{*}{ Liver } & $\mathrm{F}$ & $3.37 \pm 0.22$ & $3.28 \pm 0.31$ & $3.84 \pm 0.50$ & $3.74 \pm 0.40$ \\
\cline { 2 - 5 } & $\mathrm{M}$ & $3.13 \pm 0.13$ & $3.05 \pm 0.33$ & $3.05 \pm 0.28$ & $3.47 \pm 0.41$ \\
\hline \multirow{2}{*}{ Kidneys } & $\mathrm{F}$ & $0.72 \pm 0.06$ & $0.76 \pm 0.05$ & $0.80 \pm 0.07$ & $0.78 \pm 0.05$ \\
\cline { 2 - 5 } & $\mathrm{M}$ & $0.70 \pm 0.02$ & $0.75 \pm 0.06$ & $0.76 \pm 0.08$ & $0.76 \pm 0.01$ \\
\hline \multirow{2}{*}{ Spleen } & $\mathrm{F}$ & $0.26 \pm 0.05$ & $0.28 \pm 0.04$ & $0.30 \pm 0.03$ & $0.25 \pm 0.04$ \\
\cline { 2 - 6 } & $\mathrm{M}$ & $0.22 \pm 0.01$ & $0.25 \pm 0.06$ & $0.23 \pm 0.02$ & $0.23 \pm 0.02$ \\
\hline
\end{tabular}

Mean and standard deviation are presented $(\mathrm{n}=10 ; 5 / \mathrm{sex}) \mathrm{M}=$ Male; $\mathrm{F}=$ Female

Table 4:-Biochemical parameters for rats after 28 days of treatment with C. nardus EO.

\begin{tabular}{|c|c|c|c|c|c|}
\hline \multirow{2}{*}{ Parameters } & \multirow{2}{*}{ Sex } & \multicolumn{4}{|c|}{ Doses } \\
\cline { 2 - 6 } & & Control & $100 \mathrm{mg} / \mathrm{kg}$ & $500 \mathrm{mg} / \mathrm{kg}$ & $1000 \mathrm{mg} / \mathrm{kg}$ \\
\hline \multirow{2}{*}{ ALT $(\mathrm{UI} / \mathrm{L})$} & $\mathrm{F}$ & $32.40 \pm 6.19$ & $35.80 \pm 4.32$ & $44 \pm 8.54$ & $37.60 \pm 8.65$ \\
\cline { 2 - 6 } & $\mathrm{M}$ & $40.40 \pm 2.07$ & $39.20 \pm 6.42$ & $39.60 \pm 4.93$ & $45.40 \pm 5.37$ \\
\hline \multirow{2}{*}{ AST $(\mathrm{UI} / \mathrm{L})$} & $\mathrm{F}$ & $135.0 \pm 6.21$ & $144.2 \pm 12.62$ & $147.8 \pm 11.19$ & $149.4 \pm 11.10$ \\
\cline { 2 - 6 } & $\mathrm{M}$ & $150.6 \pm 8.56$ & $162.00 \pm 7.18$ & $153.00 \pm 4.95$ & $164.80 \pm 10.99^{*}$ \\
\hline \multirow{2}{*}{$\mathrm{TP}(\mathrm{g} / \mathrm{L})$} & $\mathrm{F}$ & $64.14 \pm 4.27$ & $60.60 \pm 2.36$ & $59.72 \pm 5.88$ & $63.98 \pm 5.25$ \\
\cline { 2 - 6 } & $\mathrm{M}$ & $62.32 \pm 2.08$ & $55.58 \pm 1.15^{* *}$ & $55.66 \pm 3.12^{* *}$ & $55.64 \pm 3.42^{* *}$ \\
\hline \multirow{2}{*}{ CREAT $(\mu \mathrm{mol} / \mathrm{L})$} & $\mathrm{F}$ & $62.98 \pm 4.84$ & $59.54 \pm 3.28$ & $57.14 \pm 3.15$ & $58.24 \pm 3.91$ \\
\cline { 2 - 6 } & $\mathrm{M}$ & $60.44 \pm 6.93$ & $54.92 \pm 3.64$ & $55.30 \pm 4.17$ & $51.18 \pm 1.32^{*}$ \\
\hline \multirow{2}{*}{ GLY $(\mathrm{mmol} / \mathrm{L})$} & $\mathrm{F}$ & $4.38 \pm 0.32$ & $4.23 \pm 0.78$ & $4.02 \pm 0.88$ & $4.49 \pm 0.30$ \\
\cline { 2 - 6 } & $\mathrm{M}$ & $4.04 \pm 0.57$ & $3.53 \pm 0.31$ & $3.73 \pm 0.15$ & $3.58 \pm 0.23$ \\
\hline \multirow{2}{*}{$\mathrm{TC}(\mathrm{mmol} / \mathrm{L})$} & $\mathrm{F}$ & $2.27 \pm 0.08$ & $1.55 \pm 0.12^{* * *}$ & $1.48 \pm 0.10^{* * *}$ & $1.66 \pm 0.14^{* * *}$ \\
\cline { 2 - 6 } & $\mathrm{M}$ & $1.70 \pm 0.10$ & $1.63 \pm 0.09$ & $1.60 \pm 0.13$ & $1.59 \pm 0.11$ \\
\hline
\end{tabular}

Mean and standard deviation are presented $(\mathrm{n}=10 ; 5 / \mathrm{sex}) \mathrm{M}=$ Male; $\mathrm{F}=$ Female

ALT: alanine aminotransferase; AST: aspartateaminotransferase; CREAT: creatinine; GLY: glycemia ; TP: total protein; TC: total cholesterol.

$* * * \mathrm{p}<0,001 ; * * \mathrm{p}<0,01 ; * \mathrm{p}<0,05 ; \mathrm{p}>0,05$ vs controls

Table 5:- Score of erythema and oedema after application of C. nardus EO.

\begin{tabular}{|c|c|c|c|c|c|c|}
\hline \multirow{2}{*}{ Rabbit $\mathbf{N}^{\mathrm{o}}$} & Flanks & \multicolumn{2}{|c|}{24 hours } & \multicolumn{2}{c|}{72 hours } & Total $(24+72 \mathrm{H})$ \\
& & Erythema & Oedema & Erythema & Oedema & Erythema + Edema \\
\hline \multirow{2}{*}{1} & Control & 0 & 0 & 0 & 0 & 0 \\
& Treated & 0 & 0 & 0 & 0 & 0 \\
\hline 2 & Control & 0 & 0 & 0 & 0 & 0 \\
\hline 3 & Treated & 0 & 0 & 0 & 0 & 0 \\
& Control & 0 & 0 & 0 & 0 & 0 \\
\hline & Treated & 0 & 0 & 0 & 0 & $\mathbf{0}$ \\
\hline
\end{tabular}


Table 6: -Score of cornea, iris and conjunctiva after applicationof $C$. nardus EO

\begin{tabular}{|c|c|c|c|c|c|c|c|c|c|c|c|c|}
\hline & \multirow{2}{*}{\multicolumn{4}{|c|}{$\frac{\text { Rabbit }^{\circ} 1}{\text { Hours }}$}} & \multirow{2}{*}{\multicolumn{4}{|c|}{$\frac{\text { Rabbit } \mathrm{N}^{\circ} 2}{\text { Hours }}$}} & \multicolumn{4}{|c|}{ Rabbit $N^{\circ} 3$} \\
\hline & & & & & & & & & \multicolumn{4}{|c|}{ Hours } \\
\hline & 1 & 24 & 48 & 72 & 1 & 24 & 48 & 72 & 1 & 24 & 48 & 72 \\
\hline \multicolumn{13}{|l|}{ I. Cornea } \\
\hline $\mathrm{A} \times \mathrm{B} \times 5(\leq 80)$ & 0 & 0 & 0 & 0 & 0 & 0 & 0 & 0 & 0 & 0 & 0 & 0 \\
\hline \multicolumn{13}{|l|}{ II. Iris } \\
\hline $\mathrm{A} \times 5(\leq 10)$ & 0 & 0 & 0 & 0 & 0 & 0 & 0 & 0 & 0 & 0 & 0 & 0 \\
\hline \multicolumn{13}{|l|}{ III. Conjunctiva } \\
\hline$(A+B+C) \times 2(\leq 20)$ & 6 & 2 & 0 & 0 & 4 & 0 & 0 & 0 & 6 & 2 & 0 & 0 \\
\hline Total & 6 & 2 & 0 & 0 & 4 & 0 & 0 & 0 & 6 & 2 & 0 & 0 \\
\hline MMTS & \multicolumn{12}{|c|}{5.33} \\
\hline & \multicolumn{12}{|c|}{ Conclusion: $2.6<$ MMTS $=5.33<15 \Rightarrow$ Minimal irritant } \\
\hline
\end{tabular}
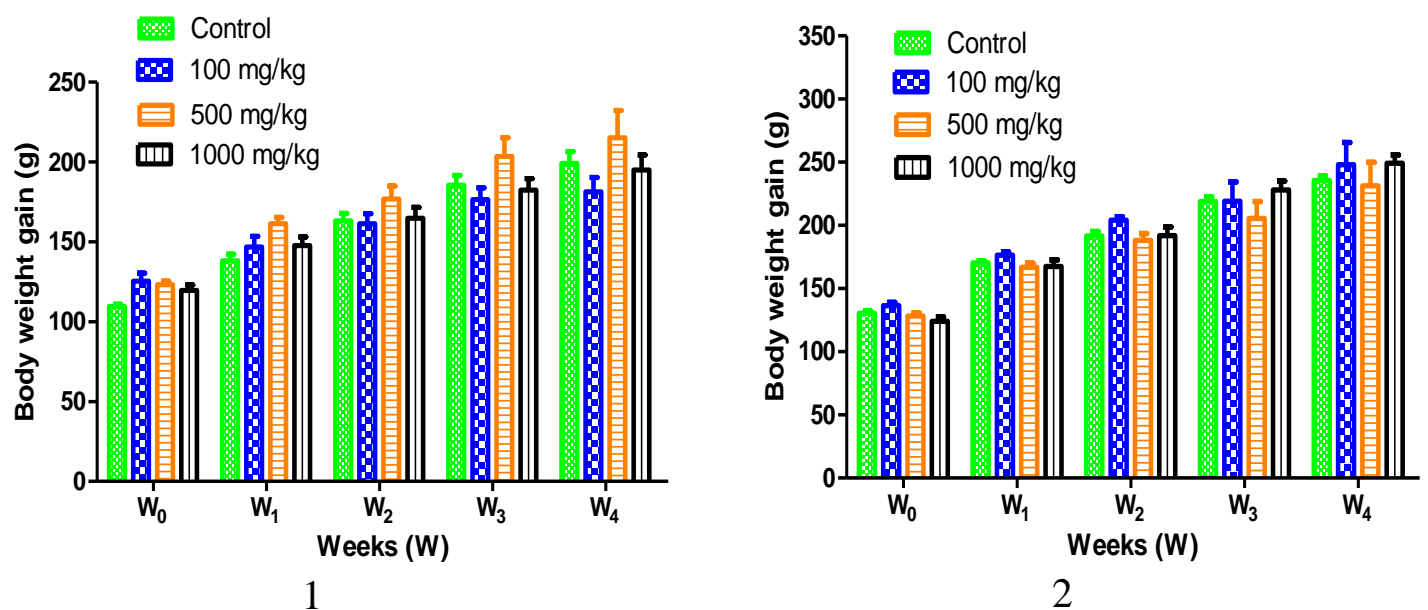

Figure 1: - Mean body weight gain of control, females (1) and males (2) rats treated with C. nardus EO ( $n=5 / \mathrm{Sex})$.

\section{Discussion:-}

EOs are odorous, volatile substances and generally liquid at room temperature. They are variable and complex mixtures of different chemical compounds, dissolved in one another, forming homogeneous solutions (Samaté, 2002). The study of the acute oral toxicity of $C$. nardus $\mathrm{EO}$ gave an $\mathrm{LD}_{50}$ estimated to $5000 \mathrm{mg} / \mathrm{kg} \mathrm{b}$.w. According to OECD guideline 423 , the EO tested is classified in the $5^{\text {th }}$ class of toxicity, that means in the class of substances with a low acute oral toxicity according to the General Harmonized System (GHS) United Nations (United Nations, 2011). This result is similar to that of US-Environmental Protection Agency (EPA) which classified C. nardus EO in the class of substances with a low acute oral toxicity with an $\mathrm{LD}_{50}>5000 \mathrm{mg} / \mathrm{kg}$ b.w. (EPA, 1997). An acute oral toxicity study carried out on mice gave $2511.89 \pm 791.5 \mathrm{mg} / \mathrm{kg}$ b.w. as an $\mathrm{LD}_{50}$ of this EO (Yoewono et al., 2016). Acute oral toxicity studies of EO of other species of Cymbopogon have also shown the absence of a toxic effect for the EO of Cymbopogon schoenanthus (LD50>5000 mg/kg b.w.) and the EO of Cymbopogon citratus (LD50 $\approx 3.5$ $\mathrm{mg} / \mathrm{kg}$ b.w.) (Costa M., 2011; Ilboudo et al., 2019).

In the sub-acute oral toxicity study, daily administration of C. nardus EO to 100,500 and $1000 \mathrm{mg} / \mathrm{kg}$ b.w. during the 28 consecutive days not showed any mortality or signs of toxicity. The results showed a non-significant increase (p> 0.05) in mean water consumption while the average food consumption of treated groups wassimilar to the control ones. According to other studies, the insignificant increase in mean water consumption could be explained by the progressive weight gain in animals and therefore, is not linked to the extract (Dawoud, 2015).These results show that the EO had no toxic effect on water and food average consumption during the four weeks study period. However, another study showed that inhalation of $\beta$-citronellol, one of the molecular components of the EO led to a decrease in the average consumption of food, after a treatment of 5 weeks (Batubara et al., 2015). In order to determine the toxic effect of the EO on animal body weights, we evaluated the bodyweight evolution of the treated 
rats compared to control ones. Results showed a non-significant increase in the bodyweight of treated animals compared to control ones. These results show that the EO did not have a toxic effect on the body weight of treated rats compared to the control ones, during the study period up to $1000 \mathrm{mg} / \mathrm{kg} \mathrm{b}$.w. However, studies have shown that the $\beta$-citronellol in the $\mathrm{EO}$ of $C$. nardus was able to induce a decrease in body weight in rats after five weeks of study in treated compared to control groups. It is the same for the EO of the schoenanthus species in a study of subacute oral toxicity (Batubara et al., 2015; Ilboudo et al., 2019). The difference between these results and this one could be explained by the difference between the species. For to evaluate the effect of the EO on certain organs, a macroscopic examination of the organs was carried out, and the results did not show any lesions, colour or shape change in the organs of the test compared to control groups. On the other hand, a non-significant increase in the relative organ weights of animals treated with EO was noted compared to the controls. This result shows that $C$. nardus EO did not have any toxic effect on the relative organ weights of the rats treated in the sub-acute toxicity study up to $1000 \mathrm{mg} / \mathrm{kg}$. Other studies have also shown the absence of lesions and histopathological signs on the vital organs of animals with the schoenanthus and citratus species after 28 days of treatment with their EO (Ilboudo et al., 2019; Lulekal et al., 2019). Certain toxins, once in the organism, can cause disturbances in biochemical parameters, thus identifying the organs concerned by intoxication. Indeed, several studies have reported that EOs of plant origin can cause, for example, hepatotoxicity, nephrotoxicity and cardiotoxicity (Doriane, 2018). However, the 28 days sub-acute toxicity study showed a slight increase in ALT and AST, while total protein, creatinine, glucose and total cholesterol levels decreased slightly in treated groups compared to control ones. The significant increase to $1000 \mathrm{mg} / \mathrm{kg}$ of blood serum AST and creatinine levels only in males treated compared to control groups cannot be linked to the extract. However, a sub-acute toxicity study carried out on mice treated with EO of $C$. nardus showed a significant increase in the level of AST at $600 \mathrm{mg} / \mathrm{kg} \mathrm{b.w.} \mathrm{(early} \mathrm{liver} \mathrm{damage)} \mathrm{in} \mathrm{the} \mathrm{test} \mathrm{groups} \mathrm{compared} \mathrm{to}$ control ones. However, the level of creatinine in the test groups remained similar to control groups at the same dose (600 mg/kg b.w.) (Yoewono et al., 2016). The significant decrease $(\mathrm{p}<0.05)$ in total protein and total cholesterol levels in all males and females respectively in treated compared to control groups, could be related to the sympathetic nerve activity in brown adipose tissue (BAT) (Shen et al., 2005). A sub-acute toxicity study carried out on rats showed that citronellal and citronellol also contained in $C$. nardus EO could cause lower triglyceride and total cholesterol levels, respectively (Batubara et al., 2015).

The skin and eye irritancy of $C$. nardus EO has been evaluated. Its DIS is between 0.00 and 0.4 . According to the classification of Draize (Draize et al., 1944), the plant's EO is classified in the first class. This means that it is classified as not irritating to the skin. Erythema and oedema being warning signs of inflammation, a study showed that $C$. nardus EO had no anti-inflammatory properties (Naidoo et al., 2009). Other studies have also shown that EOs from the schoenanthus and citratus species did not cause irritation on the skin of the rabbit (Ilboudo et al., 2019; Lulekal et al., 2019). On the other hand, the ocular irritant power gave an MMTS equal to 5.33. This value is, therefore between 2.6 and 15. According to the classification system of Kay and Calandra (Kay JH., Calandra JC., 1962), this EO is classified in the third class, that is to say among the substances with minimal irritant power on the eyes. This result is similar to that of the US-Environmental Protection Agency (EPA, 1997) which classified $C$. nardus EO as a category III eye irritant, that means in the class of substances with weak eye irritancy.

\section{Conclusion:-}

This study allowed us to assess the toxicological profile of $C$. nardus $\mathrm{EO}$. This consisted of evaluating its oral $\mathrm{LD}_{50}$, the parameters of its subacute oral toxicity as well as its skin and eye irritant power. The study of acute oral toxicity has shown that this EO has relatively low toxicity by the oral route with an $\mathrm{LD}_{50}$ estimated at $5000 \mathrm{mg} / \mathrm{kg}$ b.w. The sub-acute toxicity study of $C$. nardus EO showed low toxicity on the physical and biochemical parameters of rats. The study of irritant power has shown that it has a weak irritant effect on the skin and the eye. C. nardus EO, therefore, has low oral toxicity with very low skin and eye irritant power. This essential oil has a low toxicity and therefore presents a less toxicological risk in the event of exposure. However, its use as biopesticides should be accompanied by precautions for use for the applicator.

\section{Conflicts Of Interests:-}

The authors have not declaredanyconflicts of interests.

\section{Acknowledgments:-}

We are grateful to the "Fonds National de la Recherche et de l'Innovation pour le développement (FONRID)" for providing financial support through project $N^{\circ} 5$-AP4/FONRID. 


\section{References:-}

1. Abdoul Dorosso Samaté (2002). Compositions chimiques d'huiles essentielles extraites de plantes aromatiques de la zone soudanienne du Burkina Faso: valorisation. Thèse de Doctorat en sciences Physiques, Université de Ouagadougou. 15-264

2. Attanasio Doriane (2018). Toxicité des huiles essentielles chez les enfants. Thèse de doctorat en Pharmacie, Université de Toulouse. 14-117

3. Bassolé IH., Lamien-Meda A., Bayala B., Obame LC., Ilboudo AJ., Franz C., Novak J., Nebié RC., Dicko MH. (2011). Chemical composition and antimicrobial activity of Cymbopogon citratus and Cymbopogon giganteus essential oils alone and in combination. Phytomedicine, 12(18), 1070-1074. https://doi.org/10.1016/j.phymed.2011.05.009

4. Batubara I., Suparto I., Sadiah S., Matsuoka R., \&Mitsunaga T. (2015). Effects of inhaled citronella oil and related compounds on rat body weight and brown adipose tissue sympathetic nerve. Nutrients, 7(3), 1859-1870. https://doi.org/10.3390/nu7031859

5. Blanc-Lapierre A., Bouvier G., Garrigou A., Canal-Raffin M., Raherison C., Brochard P., \& Baldi I. (2012). Effets chroniques des pesticides sur le système nerveux central: État des connaissances épidémiologiques. Revue d'Epidémiologie et de Santé Publique, 60(5), 389-400.

6. Cherin P., Voronska E., Fraoucene N., \& De Jaeger C. (2012). Toxicité aiguë des pesticides chez l'homme. Medecine\&longevite, 4(2), 68-74.

7. Costa M. (2011). Cholesterol reduction and lack of genotoxic or toxic effects in mice after repeated 21-day oral intake of lemongrass (Cymbopogon citratus) essential oil. 49, 2268-2272. http://dx.doi.org/10.1016/j.fct.2011.06.025

8. Dawoud A. D. H. (2015). Acute toxicity studies of ethanolic extract of Eucalyptus Camaldulensis Dehnh Leaves. 2(2), 6:1-6

9. Deravel J., Krier F., \& Jacques P. (2014). Les biopesticides, compléments et alternatives aux produits phytosanitaires chimiques (synthèse bibliographique). Biotechnologie, Agronomie, Société et Environnement, 18(2), 220-232.

10. Draize J., Woodard G., Calvery H. (1944). Methods for the study of irritation and toxicity of substances applied topically to the skin and mucous membranes. J Pharm Exp Ther 82:377-390.

11. Dutok C. M. S., Berenguer-Rivas C. A., Rodríguez-Leblanch E., Pérez-Jackson L., Chil-Nuñez I., EscalonaArranz J. C., Reyes-Tur B., \&QueirozM. M. C. (2015). Acute toxicity and dermal and eye irritation of the aqueous and hydroalcoholic extracts of the seeds of "Zapote" Pouteriamammosa (L.) Cronquist. The Scientific World Journal, 1-7. https://doi.org/10.1155/2015/642906

12. H. J. Kro , S. Das and K. Tayung (2017). Antifungal activity of Cymbopogon nardus essential oil against some fungi contaminating cereals and pulses, Research Journal of Life Sciences, Bioinformatics, Pharmaceutical and Chemical Sciences (RJLBPCS). 2017;3:1-11

13. Ilboudo S., Ouédraogo G. G., Sawadogo I., Belemnaba L., \&Nébié R. C. H. (2019). Safety assessment of Cymbopogon shoenanthus (L.) Spreng. (Poaceae) essential oils: Oral toxicity, dermal and eye irritancy investigations. 2019;11:84-93

14. Ilboudo S., Toé A. M., Ouédraogo R., Ouédraogo M., \&Guissou I. P. (2014). Ecological risk assessment of pesticide residues in water from desert locust area in Burkina Faso. Research Journal of Environmental and Earth Sciences, 6(4), 227-232.

15. Kamari F. E., Taroq A., Atki Y. E., Aouam I., Oumokhtar B., Lyoussi B., \& Abdellaoui A. (2018).Cymbopogon nardus L.Essential Oil: Phytochemical screening and its antibacterial activity against clinical bacteria responsible for nosocomial infections in neonatal intensive care. International Journal of Pharmaceutical Sciences Review and Research. 03:14-17

16. Kanko C., Oussou R. K., Akcah J., Boti J. B., Seri-Kouassi B. P., \& Casanova E. J. (2017). Structure des composes majoritaires et activite insecticide des huiles essentielles extraites de sept plantes aromatiques de côte d'ivoire. International Journal of Engineering and Applied Sciences (IJEAS). 4:27-30

17. Kay JH., Calandra JC. (1962). Interpretation of eye irritation tests. J SocCosmet Chem 13:281-289.

18. Konaté A., Ouedraogo G. G., Ilboudo S., Ouedraogo N., Kabore A., Traore A., Guissou I., \&Tamboura H. (2016). Acute and Sub-acute oral toxicity studies of aqueous extrat of Securidaca longepedonculata Fresen (Polygalaceae) root barks in rodents. international Journal of advanced Research, 550-558.

19. Lulekal E., Tesfaye S., Gebrechristos S., Dires K., Zenebe T., Zegeye N., Feleke G., Kassahun A., Shiferaw Y., \&Mekonnen A. (2019). Phytochemical analysis and evaluation of skin irritation, acute and sub-acute toxicity of 
Cymbopogon citratus essential oil in mice and rabbits. Toxicology Reports, 6, 1289-1294. https://doi.org/10.1016/j.toxrep.2019.11.002

20. Multigner L. (2005). Effets retardés des pesticides sur la santé humaine. Environnement, risques \& santé, 4(3), 187-194.

21. Naidoo N., Thangaraj K., Odhav B., \& Baijnath H. (2009). Chemical composition and biological activity of the essential oil from Cymbopogon nardus (L.) Rendle. African Journal of Traditional, Complementary and Alternative Medicines, 395-395.

22. OCDE (2001) Ligne directrice pour les essais de produits chimiques, essai de toxicité orale aiguë, la méthode par classe de toxicité aiguë : $\mathrm{N}^{\circ} 423$. OCDE, Paris.

23. OCDE (2008) Ligne directrice pour les essais des produits chimiques, essai de toxicité orale à dose répétée pendant 28 jours sur les rongeurs : N407. OCDE, Paris.

24. CDE (2015) Ligne directrice pour les essais des produits chimiques, effet irritation / corrosif aigu sur la peau : $\mathrm{N}^{\circ} 404$. OCDE, Paris.

25. OCDE (2017) Ligne directrice pour les essais des produits chimiques, effet irritation / corrosif aigu sur les yeux : N405. OCDE, Paris. Organisation Mondiale de la Santé (OMS, 2004). Les enfants sont exposés à des risques élevés d'intoxication par les pesticides (https:/www.who.int/mediacentre/news/notes/2004/np19/fr/. Consulté le 16/12/2019).

26. Preludemedicinal plants database (2019). Cymbopogon nardus (L.) Rendle. https://www.gbif.org/species/2705267

27. Savadogo S., Sambare O., Sereme A., \&Thiombiano A. (2016). Méthodes traditionnelles de lutte contre les insectes et les tiques chez les Mossé au Burkina Faso. Journal of Applied Biosciences, 105(1), 10120-10133.

28. Sawadogo I., KI H., Ouédraogo A. R., Ouédraogo I., \&Nebié R. (2018). Efficacité en milieu paysan de trois bio-insecticides à base d'huiles essentielles en protection post-récolte du maïs. Spécial hors-série, Science et technique, Sciences naturelles et appliquées.04:243-250

29. Shen J., Niijima A., Tanida M., Horii Y., Maeda K., Nagai K. (2005). Olfactory stimulation with scent of grapefruit oil affects autonomic nerves, lipolysis and appetite in rat. Neurosci. Lett., 380, 289-294.

30. United Nations (2011). Système général harmonisé de classification et d'étiquetage des produits chimiques (SGH). Nations Unies. http://search.ebscohost.com

31. United States Environmental Protection Agency (EPA, 1997). Prevention, pesticides and toxic subtances, oil of citronella. r.e.d. facts. 1-6

32. Waongo A., Yamkoulga M., Dabire-Binso C., Ba M., \&Sanon A. (2013). Conservation post-récolte des céréales en zone sud-soudanienne du Burkina Faso : Perception paysanne et évaluation des stocks. International Journal of Biological and Chemical Sciences. (7):1157-11677. https://doi.org/10.4314/ijbcs.v7i3.22

33. Yoewono J. R., Purwanto R. O., Woolley C. L., Chang C.-D., \& Shih W.-L (2016). Antioxidant activities and oral toxicity studies of chamaecy paris formosensis and Cymbopogon nardus essential oils. 1(9):1-12

34. Zongo S., Ilboudo Z., Waongo A., Gnankiné O., Doumma A., Sembène M., \&Sanon A. (2015). Risques liés à l'utilisation d'insecticides au cours du stockage du niébé (Vigna unguiculata L. Walp.), dans la région centrale du Burkina-Faso. Rev CAMES. 3:25-31. 